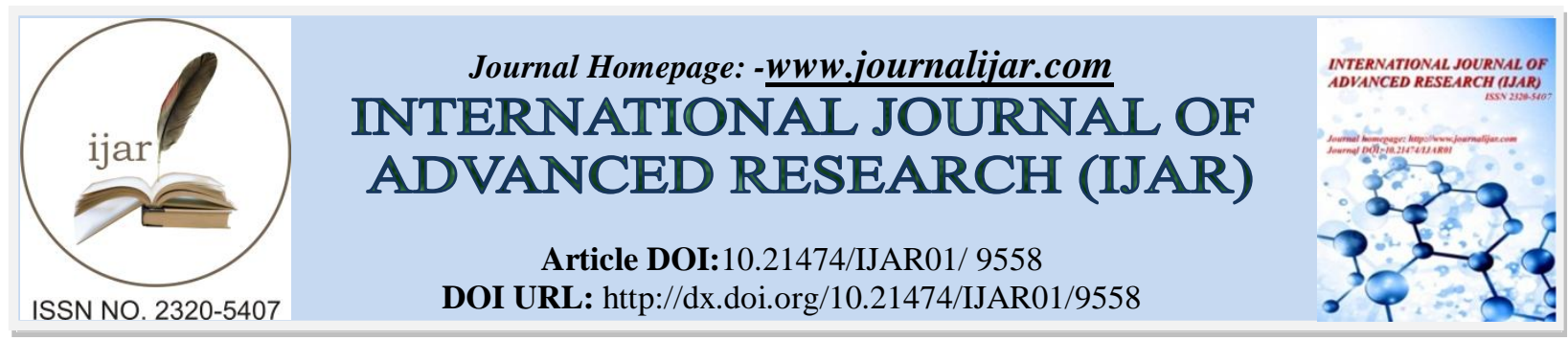

RESEARCH ARTICLE

\title{
ANATOMICAL STUDY OF FEMORAL HEAD DIMENSIONS.
}

\section{Dr. Saima Rashid ${ }^{1}$, Dr. Tawheed Ahmad ${ }^{2}$, Dr. Summaira Jan ${ }^{3}$ And Dr. Sangeeta Gupta ${ }^{4}$.}

1. Demonstrator, Anatomy, Government Medical College, Srinagar, University of Kashmir, India.

2. Assistant Professor, Surgery, KAAUH, Princess Nourah University, SA.

3. Registrar, Anesthesia, Government Dental College, Srinagar, University of Kashmir, India.

4. Professor, Anatomy, Government Medical College Jammu, University of Jammu, India.

\section{Manuscript Info}

\section{Manuscript History}

Received: 08 June 2019

Final Accepted: 10 July 2019

Published: August 2019

Key words:-

Femoral head dimensions, Femur,

Femoral head Prosthesis

\section{Abstract}

Introduction: The femur is a longest and one of the important bones in our skeletal system. As femur is composed of a very hard tissue material, thus it is one of the best preserved parts of skeleton after death and many times they are the only parts available for forensic examination.

Material \& methods: This study was conducted on 80 dry femur bones of unknown age and sex, which were obtained from Department of Anatomy, GMC Jammu. Circumference of femoral head, vertical diameter of femoral head and transverse diameter of femoral head were studied.

Result: The mean head circumference in right femur bones was 13.86 (+/- SD 1.08) centimetres (cms) with a range from 11 to $16 \mathrm{cms}$ while in left femur mean head circumference was 13.71 (+/- SD 1.13) cms with a range of 10.5 to $15 \mathrm{cms}$. The mean vertical head diameter of right and left sided femur bones was 43.51 (+/- SD 3.48) millimetres (mms) and 43.16 (+/- SD 3.74) mms respectively. Mean head transverse diameter of right and left femur bones was 42.65 (+/- SD 3.25) $\mathrm{mms}$ and 42.36 (+/- SD 3.69) mms respectively.

Conclusion: The data obtained from present study can be used as a baseline data for other studies in department of Radiology, Orthopaedics, Forensic Medicine and Anatomy. It can also be used in designing prosthesis for various orthopaedics surgeries involving head of femur.

Copy Right, IJAR, 2019,. All rights reserved.

\section{Introduction:-}

The femur or thigh bone is the longest and one of the strongest bones in the body, having length approximately onefourth of the individual's height. The body of the femur is buried in the muscles and obliquely placed, since the two femora are widely separated by the pelvis but lie close together at the knees. The femur is comprised of upper and lower ends with an intervening shaft (Gray H, 2008). ${ }^{1}$

Central to the functional complex of bipedal locomotion are the relationships between the two femora and the pelvis. Various aspects of this complex are critical to the biomechanics of gait and stride. During the process of evolution, 
as a result of bipedal stride the femur has underwent many notable changes in femoral head size, neck-shaft angle, length of shaft, Antero-posterior bowing of shaft, size of trochanters, robustness of shaft, obliquity of femoral shaft, Bicondylar width and in relative size of condyles etc. starting of body weight load borne by the femur contributed to these changes (Lovejoy CO et al, 1999). ${ }^{2}$

Sex determination is relatively easy if the entire skeleton is available, pelvis and skull are more reliable bones for this purpose. However in medico-legal cases one does not always have a complete pelvis or skull, hence it is important to be able to assess sex from the other parts of the skeleton as well. Among long bones the femur received a special attention by the researchers for this purpose (Bhosale RS \& Zambare BR, 2013). ${ }^{3}$

Long bones such as tibia and femur of the lower limb collectively remain the best options for the assessment of living stature of the individual (De Mendonca MC, 2000). ${ }^{4}$

As the femur is composed of hard tissue, they are the best preserved parts of the skeleton after death, hence at many times they are the only available parts for forensic examination and assessment (Gunay Y \& Altinkok M, 2000). ${ }^{5}$

Dislocation of the hip joint and fracture neck femur is very common in clinical practice. The knowledge about different head and neck diameters of femur is essential in orthopaedic surgery for prosthesis and nail application, as well as in radiological practice for identifying pathology of bone and also for determining the age (Chowdhury MS et al, 2012) ${ }^{6}$.

The present study was focussed on finding out the different measurements of the femoral head circumference, vertical and transverse diameter of the femoral head, which will help in radiological and orthopaedic practice.

\section{Material \& methods:-}

The study was carried out on 80 human femurs of unknown sex from Anatomy department of Government Medical College Jammu. 42 among them were right femur bones and 38 left sided femur bones. The following measurements were measured with the help of stainless steel Vernier Caliper and flexible tape.

\section{Circumference of femoral head:}

It was measured by winding the flexible tape around the circumference of head of the femur along its articular surface.

\section{Vertical diameter of head:}

It was measured as the distance between the highest and the lowest point on the articular margin of the head taken at right angle to the transverse diameter. The measuring instrument used was Vernier Caliper.

\section{Transverse diameter of head:}

It was measured using a Vernier Caliper, as the maximum antero-posterior diameter of the femur.

\section{Results:-}

Table 1:-Statistical measurement of circumference of head of right, left and total femur bones

\begin{tabular}{|l|l|l|l|}
\hline & \multicolumn{3}{|l|}{ Circumference of femoral head } \\
\hline Femur bones & Number & Mean \pm SD $(\mathbf{c m s})$ & Range $(\mathbf{c m s})$ \\
\hline Right & 42 & $13.86 \pm 1.08$ & $11-16$ \\
\hline Left & 38 & $13.71 \pm 1.13$ & $10.5-15$ \\
\hline Total & 80 & $13.79 \pm 1.11$ & $10.5-16$ \\
\hline
\end{tabular}

Table 1: shows the circumference of femoral head of right, left and all femoral bones together. Mean head circumference of right femur bones was $13.86(\mathrm{SD} \pm 1.08) \mathrm{cms}$ with a range of 11 to $16 \mathrm{cms}$ and in left femur bones $13.71(\mathrm{SD} \pm 1.13) \mathrm{cms}$ and a range of 10.5 to $15 \mathrm{cms}$. Mean circumference of femoral head of all femoral bones was $13.79(\mathrm{SD} \pm 1.11) \mathrm{cms}$ with a range of 10.5 to $16 \mathrm{cms}$. The mean head circumference of right sided femur bones was slightly more than the left sided femur bones.

Table 2:-vertical diameter statistical measurements of femoral head in right and left femur bones 


\begin{tabular}{|l|l|l|l|}
\hline Femur bones & Number & Mean \pm SD(mm) & Range(mm) \\
\hline Right & 42 & $43.51 \pm 3.48$ & $35-50.2$ \\
\hline Left & 38 & $43.16 \pm 3.74$ & $32.6-49.4$ \\
\hline Total & 80 & $43.34 \pm 3.59$ & $32.6-50.2$ \\
\hline
\end{tabular}

Table 2: shows the femoral head vertical diameter of right and left sided femoral bones. The mean femoral head vertical diameter of right sided femur bones was 43.51 (SD \pm 3.48 ) $\mathrm{mm}$ with a range of 35 to $50.2 \mathrm{~mm}$ and of left sided femoral bones was 43.16 ( $\mathrm{SD} \pm 3.74) \mathrm{mm}$ with a range of 32.6 to $49.4 \mathrm{~mm}$. Mean vertical diameter of head of all femoral bones was $43.34(\mathrm{SD} \pm 3.59) \mathrm{mm}$ with a range from 32.6 to $50.2 \mathrm{~mm}$. The mean vertical femoral head diameter of right sided femur bones was slightly more than left femoral bones.

Table 3:-Statistical measurement of right and left femoral head transverse diameter

\begin{tabular}{|l|l|l|l|}
\hline \multirow{2}{*}{ Femur bones } & \multirow{2}{*}{ Number } & Transverse diameter of femoral head & \\
\cline { 3 - 4 } & 42 & Mean \pm SD(mm) & Range(mm) \\
\hline Right & 38 & $42.65 \pm 3.25$ & $34.6-48.7$ \\
\hline Left & 30 & $42.51 \pm 3.49$ & $33-48.5$ \\
\hline Total & 80 & $33-48.7$ \\
\hline
\end{tabular}

Table 3: shows the right and left femoral head transverse diameter. The mean transverse femoral head diameter of right sided femur bones was $42.65(\mathrm{SD} \pm 3.25) \mathrm{mm}$ with a range of 34.6 to $48.7 \mathrm{~mm}$ and of left sided femur bones was 42.36 ( $\mathrm{SD} \pm 3.69) \mathrm{mm}$ with a range of 33 to $48.5 \mathrm{~mm}$. The mean transverse head diameter of all the femoral bones was $42.51(\mathrm{SD} \pm 3.44) \mathrm{mm}$ with a range of 33 to $48.7 \mathrm{~mm}$. The mean transverse head diameter of right sided femur bones was slightly more than left sided femur bones.

\section{Discussion:-}

In this study the mean values of circumference of femoral head on right and left sided femoral bones was $13.86 \pm 1.08$ and $13.71 \pm 1.13 \mathrm{~cm}$ respectively that match with the result of Silva VJ et al, $\mathbf{2 0 0 3}^{\mathbf{7}}$ who found mean circumference on right side as $13.39 \pm 1.02 \mathrm{cms}$ and on left side as $13.68 \pm 0.9 \mathrm{cms}$. Osorio $\mathbf{H}$ et al, $\mathbf{2 0 1 2}{ }^{8}$ in their study on circumference of femoral head found its value slightly higher than the present study which had the values of $14.49 \pm 0.94$ and $14.17 \pm 1.56 \mathrm{~cm}$ respectively on right and left side.

Jayachandra Pillai T et al, $2014{ }^{9}$ found mean values of vertical diameter of femoral head as $41.63 \mathrm{~mm}$ and 42.96 $\mathrm{mm}$ on right and left side respectively and hence their values were slightly less than our present study. Ozandac $\mathbf{S}$ et al, $2015{ }^{10}$ also studied same parameter and their values were more than our present study.

Ziylan T \& Murshid KA, $2002{ }^{11}$ in their study found mean values of transverse diameter of femoral head $44.7 \pm$ $4.1 \mathrm{~mm}$ and $44.3 \pm 3.3 \mathrm{~mm}$ on right and left side respectively, their values were slightly more than the present study. The values of our present study were more than the values obtained in a study done by Khaleel N \& Shaik HS, $\mathbf{2 0 1 4}{ }^{12}$ which were $37.74 \pm 3.05 \mathrm{~mm}$ on right side and $38 \pm 3.13 \mathrm{~mm}$ on left side.

\section{Conclusion:}

The different dimensions of femoral head obtained in this study will help in designing a better fitting femoral head prosthesis that are used in hip replacement surgeries.

\section{Bibliography:-}

1. Gray H. Pelvic girdle, gluteal region and thigh. In: Standring S, Borley NR, Collins P, Crossman AR, Gatzoulis MA, Healy JC, et al (editors). Gray's Anatomy: The Anatomical basis of clinical practice. $40^{\text {th }}$ ed., London: Chruchill Livingstone Elsevier; 2008. pp. 1349-85

2. Lovejoy CO, Cohn MJ, White TD. Morphological analysis of the mammalian postcranium: A developmental perspective. P Natl Acad Sci 1999;96(23):13247-52

3. Bhosale RS, Zambare BR. Sex determination from femur using length of femur in Maharashtra. J Dent Med Sci 2013;3(4):1-3

4. De Mendonca MC. Estimation of height from the length of long bones in a Portuguese adult population. Am J Phys Anthropol 2000;112(1):39-48 
5. Gunay Y, Altinkok M. The value of the size of foramen magnum in sex determination. J Clin Forensic Med 2000;7(3):147-49

6. Chowdhury MS, Naushaba H, Mahbubul Mawla Chowdhury AHM, Khan LF, Ara JG. Morphometric study of fully ossified head and neck diameter of the human left femur. J Dhaka Natl Med Coll Hos 2012;18(2):9-13

7. Silva VJ, Oda JY, Santana DMG. Anatomical aspects of the proximal femur of adults Brazilians. Int J Morphol 2003;21(4):303-08

8. Osorio H, Schorwer K, Coronada C, Delgado J, Aravena P. Proximal femoral epiphysis anatomy in Chilean population. Orthopedic and forensic aspects. Int J Morphol 2012;30(1):258-62

9. Jayachandra Pillai T, Lakshmi Devi CK, Sobha Devi T. Osteometric studies on human femurs. J Dent Med Sci 2014;13(2):34-39

10. Ozandac S, Goker P, Yucel AH, Bozkir MG. An osteometric study of proximal and distal femur morphology. Cukurova Med J 2015;40(3):466-73

11. Ziylan T, Murshid KA. An analysis of Anatolian human femur anthropometry. Turk J Med Sci 2002;32:231-35

12. Khaleel N, Shaik HS. Osteometric study of human femur. Int J Res Med Sci 2014;2(1):104-07. 